\title{
Managing Machu Picchu: institutional settings, business model and master plans
}

\author{
Luca Zan and Maria Lusiani \\ University of Bologna, Bologna, Italy
}

\begin{abstract}
Purpose - The purpose of this paper is to analyze elements of continuity and change in the administrative history of the Historical Sanctuary of Machu Picchu (HSM) over the last decade.

Design/methodology/approach - Based on a field study and of both qualitative and quantitative data, the paper reconstructs changes in accounting and planning processes and discourses.

Findings - At the macro level, in the recent past Peru has gone through a process of modernization of the State, moving to more transparent and accountable forms of public management that deeply restructured the public sector. In parallel, the international community (particularly, UNESCO) has urged the adoption of a comprehensive strategic management plan for the HSM. Common to these pressures for change is a logic of efficiency, of rationalization and control of public expenditures and of more effective public services. At the micro level, these two pressures for change are shaping both the transformation of the accounting representation system and the managerial and planning practices in Machu Picchu.

Originality/value - The paper focuses on a description of the institutional settings in order to make sense of the multiple rationalities involved; second, a reconstruction of the underlying "business model" of the main entity involved in the administration of Machu Picchu (in terms of internal structure and scope, visitor performance, financial performances, human resources); and third, a focus on the progressive introduction of master planning as a practice.
\end{abstract}

Keywords Peru, History, Cultural heritage, Tourism, Sustainable development,

Management of World Heritage sites, Management, Museum

Paper type Research paper

\section{Introduction}

Much has been said and written about Machu Picchu from very many different perspectives: its sensational discovery in 1911 by Hiram Bingham, its identity as one of the most enigmatic ancient sites in the world, its inscription on the UNESCO World Heritage List in 1983 and, more recently, its nomination as the seventh wonder of the world. Further, Machu Picchu is caught between the explosion of tourists and the exploitation of a site, between the protection of inestimable heritage and speculative economic interests related to tourism - and will Machu Picchu be inserted in the blacklist of heritage sites at risk?

This paper addresses the managerial dimension of Machu Picchu, its continuity and change in recent decades. We are interested in unraveling the knotty

Several people have been fundamental in allowing this paper to be completed. The authors would like to thank especially Arch. Jorge Zegarra Balcazar, at that time INC-Cusco Director, Fernando Astete, Director of the Historical Sanctuary of Machu Picchu, Arch. Jorge Prado Tisoc, Chief of the International Cooperation Office of INC-Cusco, and the whole staff of INC-Cusco and HSM for welcoming the authors and providing rich documentation on the institution during the authors' visit to Peru in 2008. Many thanks also to Roberto Chavez for his precious suggestions for the research.

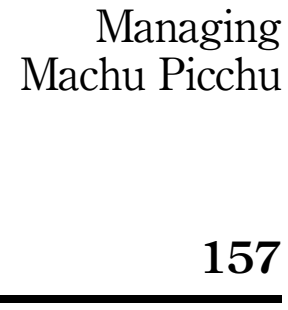


JCHMSD

1,2

158 situation of managing a site that is highly visible, highly profitable, highly discussed, and at the crossroad of multiple convergent and often conflicting interests. We will do so by reading the situation from an organizational and administrative perspective.

Machu Picchu represents an insightful case in the debate about the relationship between the historical value of heritage and its commercial exploitation, which often calls for by managerial approaches in similar entities (for a literature review see Zan, 2006; Lusiani and Zan, 2010).

In particular, our analysis will focus on three main aspects: first, a description of the institutional settings in order to make sense of the multiple rationalities involved; second, a reconstruction of the underlying "business model" of the main entity involved in the administration of Machu Picchu (in terms of internal structure and scope, visitor performance, financial performances, human resources); third, a focus on the progressive introduction of master planning as a practice.

This paper is based on qualitative and quantitative information gathered during two field visits as independent researchers (May 2007 and May-June 2008), including 30 in-depth interviews with administrative personnel of the Instituto Nacional de Cultura del Cusco (INC-Cusco), and direct observations of meetings between a World Bank delegation, local professionals, and City Mayors. In addition, it is based on analysis of legislative documents; press articles; literature on Peru's political/ administrative system; UNESCO, World Bank and ICOMOS reports on Machu Picchu; and internal management plans.

\section{Institutional settings: a situation of conflict}

Positioning Machu Picchu in its overarching political, administrative, and institutional context is an indispensable preliminary digression in order to capture specificities and problems of the case.

\section{The administrative/political context}

A first issue regards the political/administrative context (for an overview see: The World Bank, 2002, 2006; APEC, 2007; ICE, 2007). Since the preservation of cultural heritage is one of the duties of the State and is carried out through the action of public institutions, major transformations of the public sector have organizational implications for cultural heritage preservation actions[1]. Here more than elsewhere, this has meant a huge process of change in recent decades: the controversial era under President Fujimori in the 1990s, and the transformation of the State related to the recovery of the democratic system from the 2000s. There are very important discontinuities in this history of political/administrative context: the overarching project of "Modernizing the management of the State"[2] in the political agenda of the last decade, had important technical changes associated with it such as a major decentralization process in the public sector and the regularization of the national public investment system, with important impacts on the management of human resources. Given the space limitations in this paper we will focus on the major implications of these overarching political and administrative changes for understanding change in Machu Picchu (for further details see box 1 in the virtual appendix, available on SSRN at http://papers.ssrn.com/sol3/papers. cfm?abstract_id=1745322). 
The nature of Machu Picchu

The second issue in order to position Machu Picchu in its context has to do with its delimitation. What we refer to when we speak about Machu Picchu is much more than what is commonly perceived (Figure 1):

- Its area goes far beyond the delimitation of the Inca City. The Historical Sanctuary of Machu Picchu (HSM or "the Sanctuary" hereinafter) has an area of $32,592 \mathrm{ha}$ and a perimeter of $116 \mathrm{~km}$.

- In addition, the monumental Inca City cannot be appreciated separately from the natural environment in which it is embedded. From an historical perspective the sacred meaning of the area is grounded in its profound relationship with the surrounding natural dimension. HSM embodies the extended, transectoral concept of cultural heritage, belonging to the historical/artistic/anthropological sector as well as to the physical/biological/geological one. Indeed, in 1983 the HSM was declared part of the world cultural and natural heritage by UNESCO for the exceptional value of both dimensions.

- Moreover, and also in archaeological terms, Machu Picchu is much more than just the Inca City everybody evokes, which is just one spot in a network of archaeological sites diffused throughout the whole territory of the Sanctuary. To give an idea, the archaeological heritage within the area of the HSM counts 196 archaeological sites divided into four macro-zones (Mountains, Inca trail, Sacred Valley, Sacred River).

Institutional fragmentation: HSM as an arena of conflicts

If institutional fragmentation is a general phenomenon in Peru (Giugale et al., 2006, pp. 27-8), the protected area of Machu Picchu provides a typical example of such a situation, with serious potential conflicts. Little would be understood about managing Machu Picchu if an analysis of the conflicting interests involved were not attempted.

Machu Picchu lies at the crossroad of multiple, often conflicting interests at a variety of levels that need to be disentangled. First there is a direct, immediate conflict of jurisdictions between two ministries. The double dimension of the Sanctuary (natural and cultural) entails an overlapping of the jurisdictions of the Ministry of Education with the INC on the one side; the Ministry of Agriculture with the Instituto Nacional de Recursos Naturales (Inrena) on the other one. Or, to put in different words, the organizational boundaries of any specific entity do not coincide with the area of the site.

Second, there is a further conflict of jurisdiction between institutions: INC and Inrena on the one side and the local government on the other (the municipality of Aguas Calientes, also known as Machu Picchu Pueblo). The area of the Sanctuary roughly coincides also with the political-administrative jurisdiction of the local government. The problem here lies in the typical difficult trade off between preservation goals and the social, economic, territorial, and occupational nature of local government interests. The conflict is sharp in this case in particular. Given the poverty of the local population and the huge opportunity to "make money" in Machu Picchu with tourism, the economic, even speculative, interests of the local government are extremely high. It should be underlined that Machu Picchu is perhaps one of the richest - most "profitable" - archaeological sites of the world (see Table I), where all visitors spend at least US\$150 per day (just think of the difference with Pompeii, where the train costs about $€ 2$, and the ticket $€ 10$ ).

\section{Managing Machu Picchu}

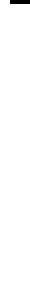


JCHMSD

1,2

160
Figure 1.

Map of the Historical Sanctuary of Machu Picchu (HSM)

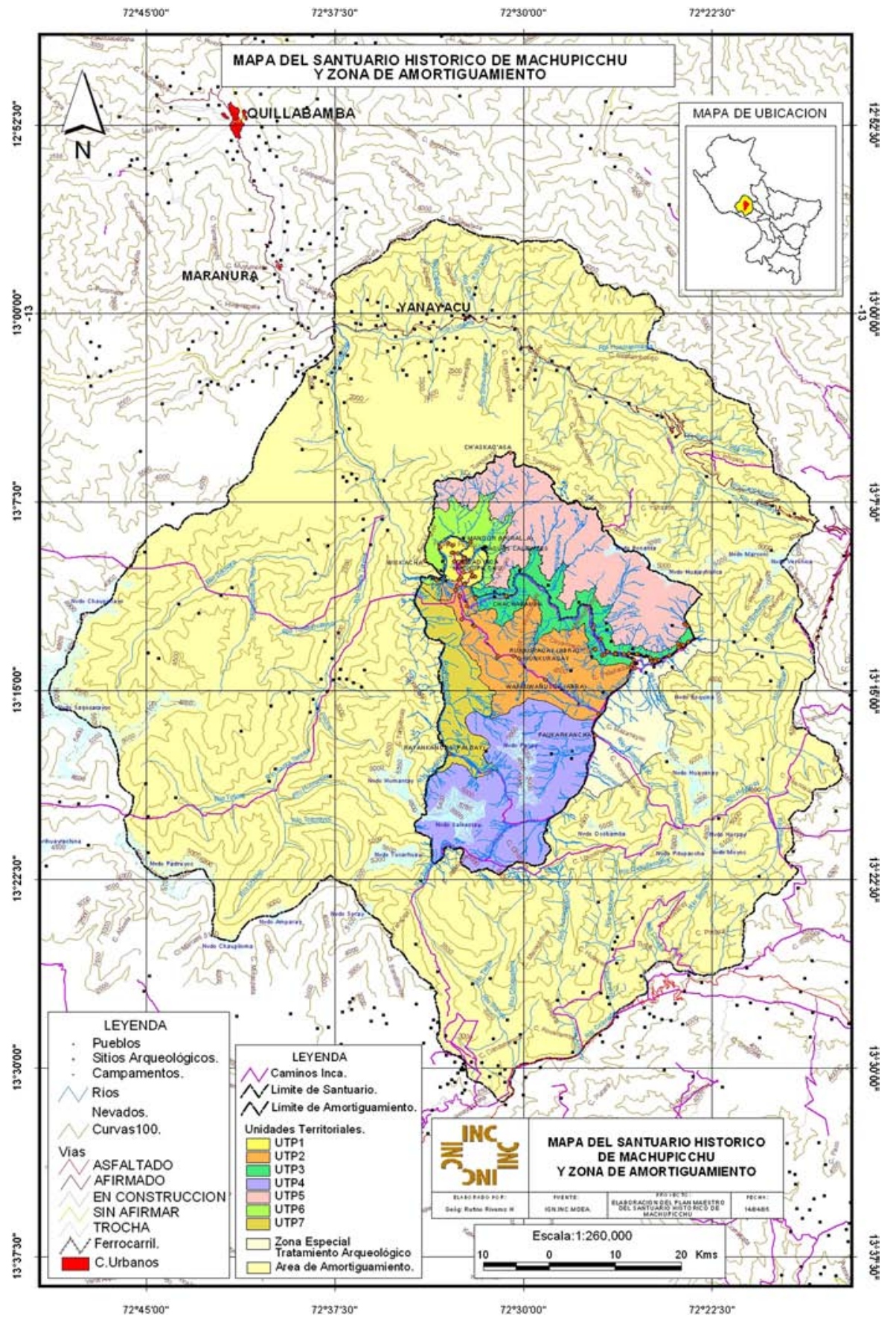


Aguas Calientes is a small city created 50 years ago in the valley beneath the Inca City of Machu Picchu exclusively and explicitly to exploit the externalities of tourism. The birth and growth of Aguas Calientes paralleled the establishment and the increase of tourism; a mass of "immigrants" from all over Peru were attracted into the area by the opportunity for easy, fast, and rentable investments. Private interests and speculation are dominant in the municipality of Aguas Calientes and, in general, the local government tends not to recognize the authority of INC or Inrena. The main problem is the uncontrolled urban expansion and all the related effects (health problems, solid waste management problems, pollution) in an area that not only lies within a protected natural park and within a historical sanctuary, but is also endangered by environmental threats (frequent floods and landslides, in particular) that have of course become more severe under urban pressure.

The two institutions (INC-Cusco and Inrena) have formal juridical power and can oppose municipal actions, but faced with these strong economic interests and corruption the entities fail to effectively intervene. Actually, the whole Peruvian justice system does not seem effective in defending cultural heritage (despite the rhetoric of the legislation in this sector): State justice intervenes very slowly while illegitimate buildings and activities have already expanded and become rooted (interview with the chief of Inrena and Memorias de gestión 2003-2006).

Third, there may be some sort of cultural conflict between the indigenous rationality and the rationality of international organizations (UNESCO in particular) involved in the area, or between "local" and "global" administrative trends. In 1983 the HSM was declared a World Heritage Site by UNESCO because of its outstanding universal value. Being under special protection implies that the preservation, conservation, and enhancement of the world heritage site - although primarily conducted by the State through its institutions - are also executed in cooperation and with the technical assistance of the international community (Articles 4 and 7 of the UNESCO Convention). Since 1983 then UNESCO has undertaken a continuous process of monitoring, assessing, and assisting all activities concerning the preservation of Machu Picchu, playing a very crucial role in limiting its commercial exploitation.

Also the World Bank is collaborating with the government of Peru since 2005 in the Vilcanota Valley Rehabilitation Project. In this framework the Bank accorded a loan of US\$8 million to the Government of Peru (Ministry of Foreign Affairs and Tourism) for a four-year period and is coordinating the implementation of a large number of interventions in the whole Vilcanota Valley where the HSM is located.

\section{Train}

96-132

Bus

9

6

2

Fees

40

20

20

10
Cusco-Machu Picchu return

Various options

From Aguas Calientes to Machu Picchu (6 km)

Foreigners

National population

Local population

Entrance to the Inca City of Machu Picchu

Foreign adult ticket

Foreign student

Peruvian adult

Peruvian student

\section{Managing \\ Machu Picchu}

161 
JCHMSD

1,2

162

\section{INC-Cusco: the underlying business model}

Though our main interest is the managing of the HSM as such, a focus on INC-Cusco - the entity in charge of heritage protection in the region, both tangible and intangible, one of the richest areas of Peru - is indispensible, for two main reasons:

- in organizational terms, the Archaeological Park of Machu Picchu is not a "stand alone" institution, but rather an internal division of INC-Cusco. Several elements of its functioning are thus defined by the higher level of the organization; and

- most importantly, in financial terms the relationship between the two entities is crucial for understanding the "business model," the inner economy of heritage in the area and in Machu Picchu: where money comes from, where it is are used, and important elements of internal cross-subsidization, as in any organization. Interestingly enough, a precise reconstruction of financial flows as in Figure 2 was not available to either UNESCO and the World Bank during the Vilcanota project.

\subsection{Internal structure and scope}

INC-Cusco is a very complex organization, a sort of portfolio of individual entities, tasks, and departments that are related to the great number of archaeological sites in the region. In addition to HSM, it directly manages several important sites (Museo de Sitio de Machu Picchu, Museo de Sitio de Chinchero, Tipon, Tarawasi, Raqchi, Moray, Pikillaqta, Choquequirao, Huchuy Qosqo), plus the sites in the Sacred Valley and surrounding Cusco city that are managed by the municipality using human resources and competences of INC-Cusco (including Pisaq, Chinchero, Ollantaytambo, Saqsaywaman, Q'enqo, Puka Pukara, and Tambomachay). In addition, other internal departments are associated to major projects (Cusco's historical centre, another UNESCO site, the Qhapaq Nan project, etc.), as well as internal offices (Figure 2).

Figure 2.

Instituto Nacional de Cultura del Cusco (INC-Cusco), organizational chart

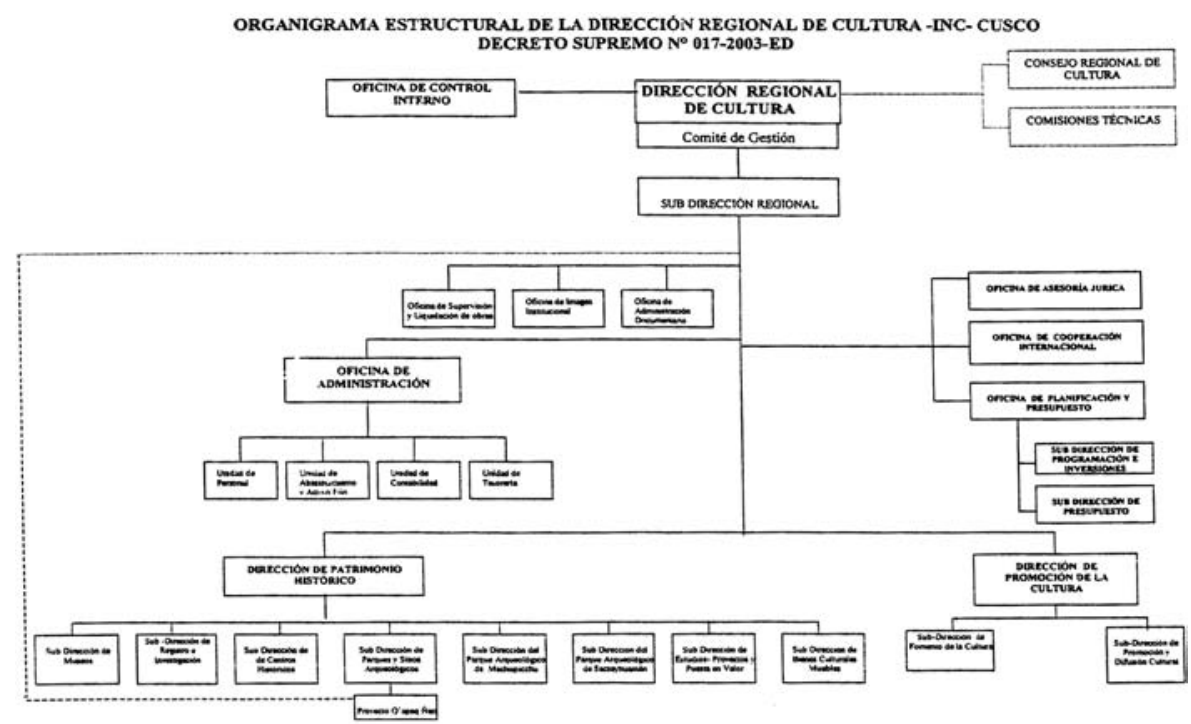

Source: INC-Cusco 
Following the general wave of decentralization in the country as a whole, in 2003 INCCusco gained a new, special status of autonomy[3]. While the actual degree of decentralization is often questioned by inner actors (the same law indeed explains that INC-Cusco "maintains its condition of decisional unit") there are important impacts of the general process of transformation affecting any organizational analysis, particularly in terms of financial and human resource management.

\subsection{Tickets and inflows}

A crucial aspect in the management of heritage in Cusco must be underlined: money from tickets in the area is kept at the local level, and furthermore the area is almost totally self-funded. Just marginal amounts are transferred through the national budgeting procedure (in 2007, 1 out of 82.5 million Soles of total inflows - 1 Soles equal $€ 0.272$ ). An exception is represented by sites run in cooperation with Oficina Ejecutiva del Cusco (OFEC , an entity run by the municipality), where INC-Cusco simply get a portion of revenues from OFEC. Some general inflows are also present.

From a substantive point of view some comments on inflows can be pointed out based on the situation in 2007 (Table II):

- the Inca City of Machu Picchu (70.6 percent) and Inca Trail (17.5 percent) account for 88 percent of total inflows of the whole area;

- the sites managed through OFEC have some financial importance (10 percent), though the rules governing the distribution of margins between the municipality and INC-Cusco are a subject of controversy; and

- the rest of the heritage directly managed - though important from an historical and archaeological point of view - have a very marginal impact in terms of inflow (1.3 percent), as well as other inflows (0.7 percent).

In terms of dynamics (Figure 3), sustained growth can be found: in 2007 inflows at Machu Picchu were almost four times the value in 2002 and seven times those of 1999. Although there has been considerable inflation, trends in ticket inflows show a dramatic explosion in visitor numbers, combined with an increase in the ticket price to enter Machu Picchu. In particular, the number of visitors has doubled in the last seven years, to the impressive number of 800,000 in 2007.

Such a trend in visitors is a crucial element in the whole discourse about managing Machu Picchu, directly linked to the delicate trade-offs between exploitation and conservation of the site:

- One of the most interesting elements to be noted (Figure 3) is that not all inflows are kept by INC-Cusco as such. Indeed the Municipality of Aguas Calientes has received 10 percent of entrance fees from Machu Picchu since 2004. The history of how this decision was made deserves a paper of its own. Of the remaining real captado (income before transfers) of 81.5 million Soles, 70 percent is kept by INC-Cusco as a whole, 15 percent is redirected to the Qhapaq Nan project in Cusco, and 15 to the Qhapaq Nan project in Lima.

- An explosion of visitor numbers also emerges - which is perceived as a threat to the preservation of the site by international experts, UNESCO in particular. The seasonal breakdown of data (Table III) shows that in peak months about 90,000 people visit the sites: an average of 3,000 per day, well above the 2,500 level established by the plan itself.

\section{Managing Machu Picchu}

163 
JCHMSD

1,2

164

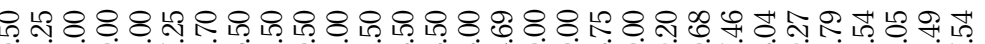
ต

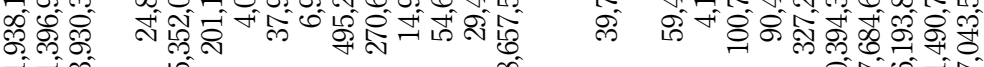
०ी

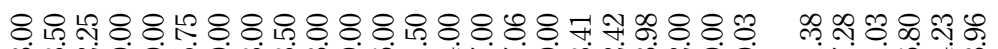

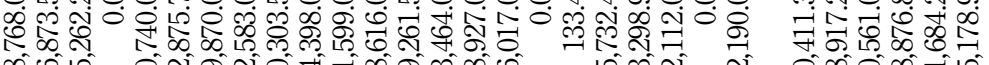

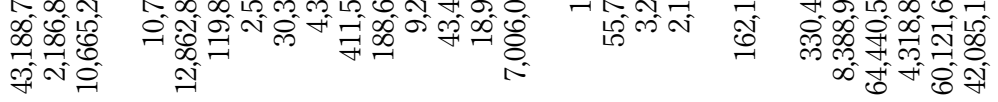

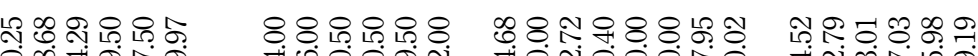

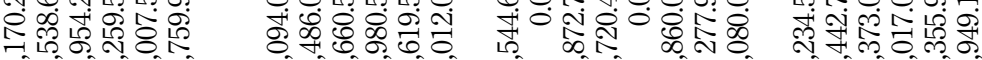

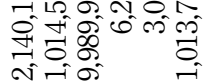
กं

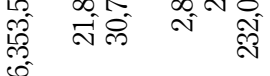
लि तिक्ठ के से के

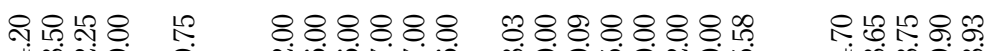

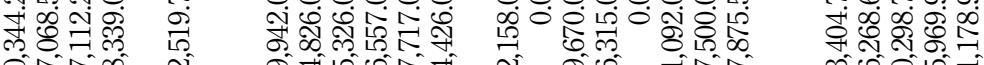

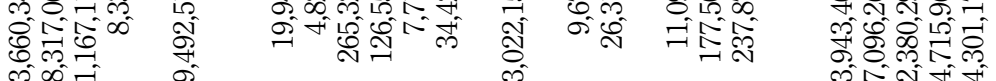

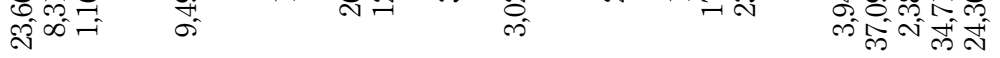

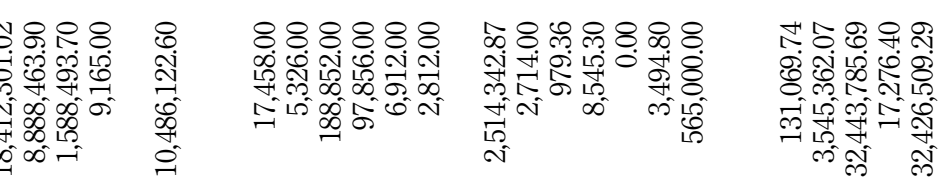

Table II.

INC-Cusco financial results

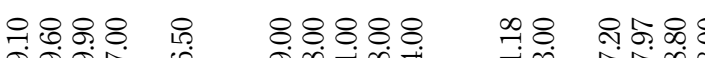
눙요 \& 荡等

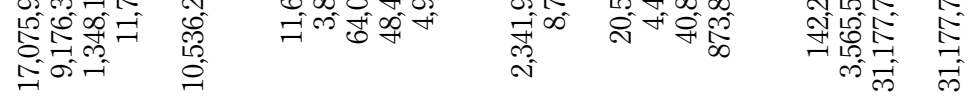

ชి

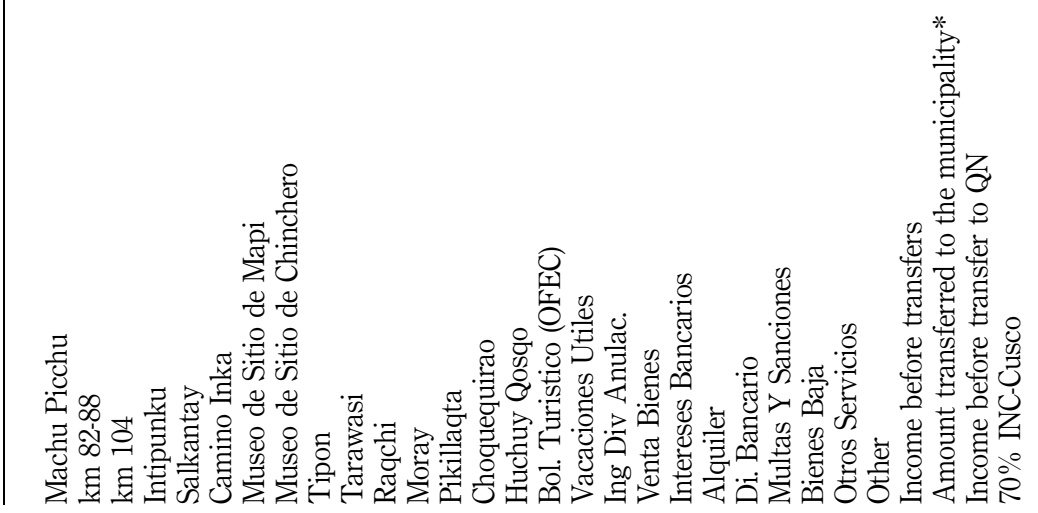




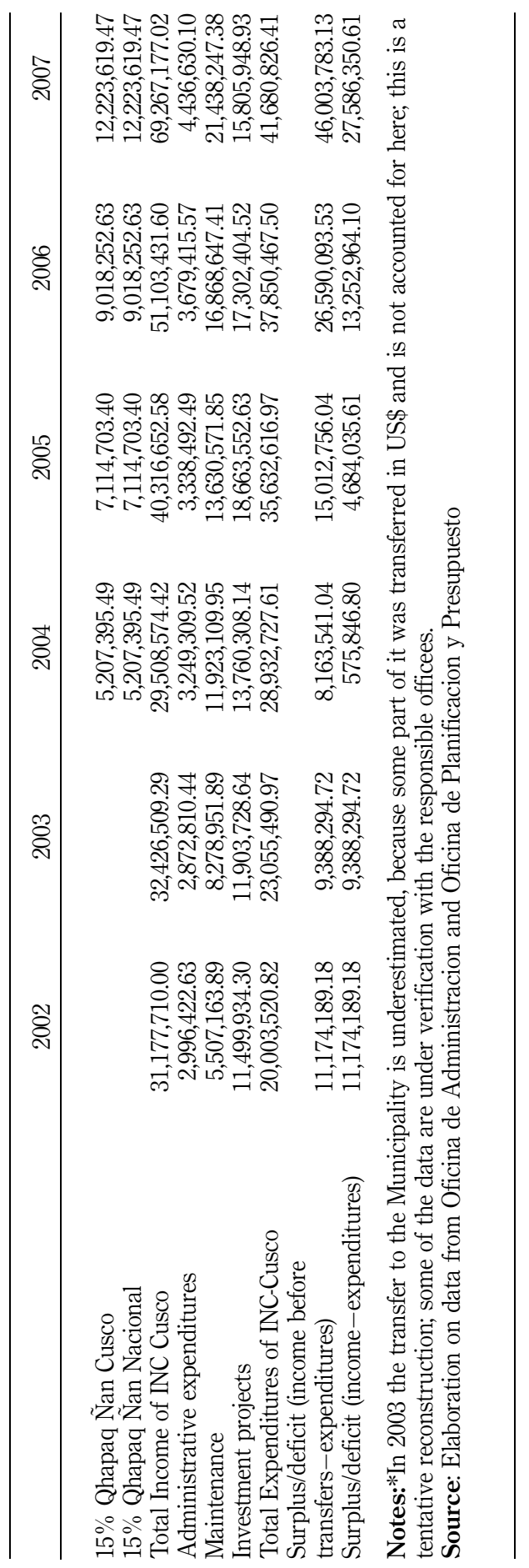

Managing
Machu Picchu

165

Table II. 
JCHMSD

1,2

\section{6}

Figure 3.

Visitors (1990-2007)

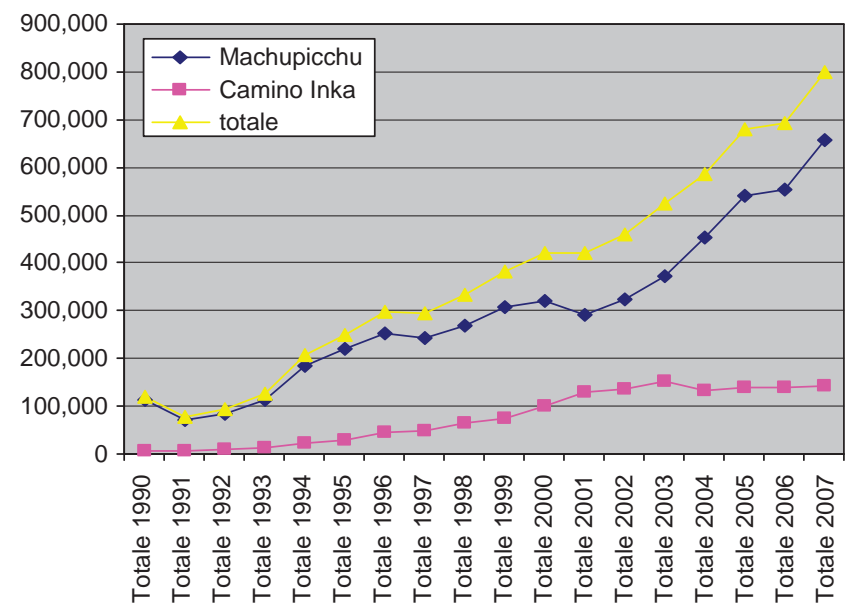

\subsection{Financial performance}

As mentioned, within a general effort to fight corruption, a system for controlling the destination of public expenditure (SNIP) has been gradually introduced by law in Peru since 2000. This represents another important reform in a logic of the modernization of the State (see box 2 in the virtual appendix). In 2003 the system was applied to cultural heritage and to INC as well.

In procedural terms, this had a rather unusual impact on accounting representation. According to a long-standing tradition, costs are divided in three different classes: administrative, operating (actividad), and investment (inversiones). Any project of refurbishment, restoration, or conservation for INC-Cusco is defined as "investment," and thus has to follow the national SNIP application. One could argue that from a managerial point of view, conservation and restoration are simply current, typical activities of this type of organization, and indeed should be seen as ordinary routines (and thus current costs). However, national priorities, first of all fighting corruption, have their rationality (and anyway the strength to impose their agenda), and thus such a distinction must be accepted. Unfortunately, this impacts normal accounting tools, to a large extent reducing transparency for the external reader of financial statement. In the Estado de Gestion (income and expenditure statement) report, only current costs are listed, while all inversiones - though carefully tracked by the cost accounting system - are capitalized as assets in the balance sheet. As a result, the income statement is useless for analyzing the uses of resources. For instance, in 2007, with 82.5 million soles of income, 26.2 million in costs and expenditures were listed, leaving an operating margin of 56.3 million. Considering other inflows and expenditures, a net result of 53.3 million is presented (64 percent!), which would be wrong to compare to the notion of surplus in any other accounting system.

The external reader would have serious problem in relating these numbers to actual financial dynamics. Fortunately, we were provided data from the internal costing systems (Table IV), addressing important phenomena:

- Almost half of total gastos (expenditures) (41.7 million) are for current activities (51.4 percent), while 10.6 percent are for administrative expenditures, and 37.9 percent for inversiones. 


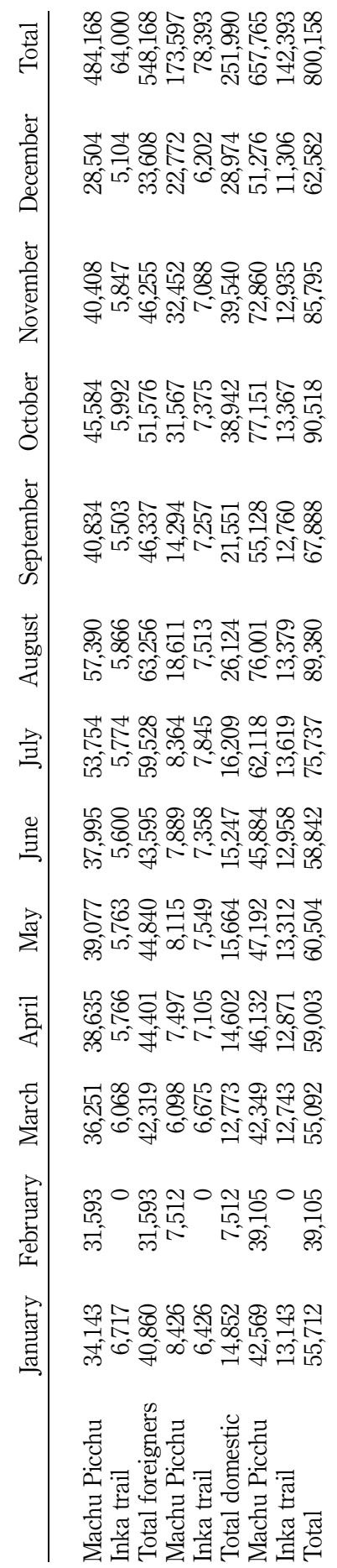

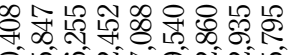

Managing Machu Picchu

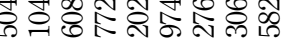

ง เก ถึ่

of

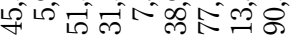

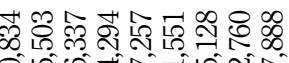

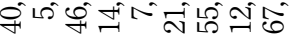

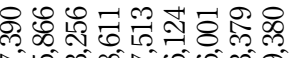

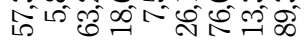

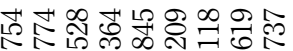

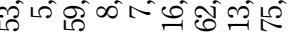

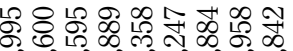

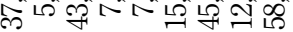

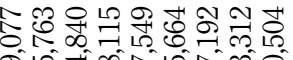

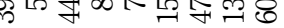

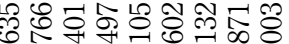

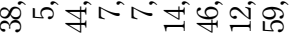

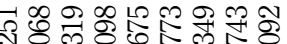

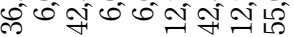

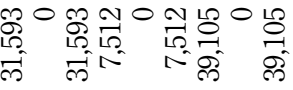

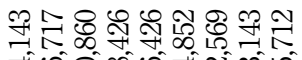

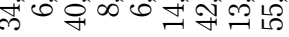

Table III. HSM monthly visitors 
JCHMSD

1,2

168

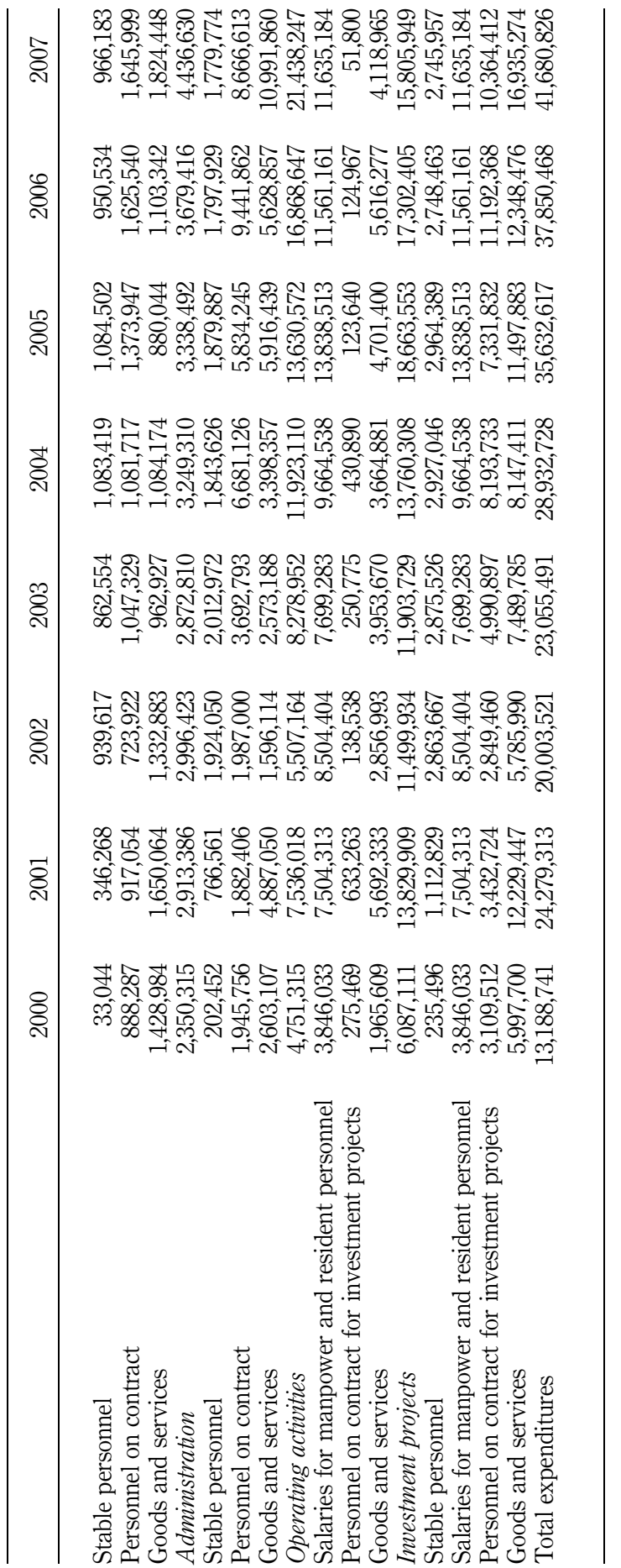

Table IV.

ICN Cusco: Breakdown of expenditures 
- In terms of type, total expenditures can also be divided in terms of salaries for full time employees (6.6 percent); salary for ad hoc, temporary personnel employed in both administrative and operational activities (27.9 percent); salary for personnel employed on investment projects (24.9 percent), and good and services purchased (40.6 percent). While the total amount of salary per se is not surprising, what is really unusual is the limited role of salary of "normal" employed, as we will see looking at HR management.

The rate of growth in administrative and operating expenditures appears to be higher than growth in investment, especially in recent years (Figure 4). Despite the large amounts available, the implementation of SNIP procedures within the INC in recent years - and particularly from 2005, following the establishment of the new Plan Maestro - show a decline in ready investment projects, due to delayed approval by the SNIP offices. In other words, the crucial underlying process of redirecting managerial attention to a new set of investments, which was shaped within the new plan and made possible by the new resources created by the increase in visitor inflows, is hidden by the parallel phenomenon of a new, complex national accounting procedure, the SNIP.

\subsection{Human resources}

One of the most difficult things to understand in any context is the question of human resources. Though deeply embedded in social and historical traditions, and especially in the public sector subject to different countries' idiosyncratic processes of change or inertia, human resources are, however, a crucial variable. Management, in heritage as elsewhere, is basically an issue of managing people.

No civil servants have been hired in Peru since 1991, under a general rule established by then President Alberto Fujimori. The result has been a massive use of contract workers to an extent rarely seen elsewhere. Out of 2,751 people currently working at INC-Cusco, only 123 are full time employees. The rest are on contract, with a variety of solutions for the 1,203 people working on administrative and operating activities, even including skilled workers and responsibility managerial positions.

Furthermore, on a strictly project basis the remainder work on investment projects, including directive staff and project managers $(80)$ and workers $(1,345)$, always hired with short term contracts (visiting a site in Cusco at the beginning of June, we saw groups of workers waiting a for job call, echoing the movie "On the Waterfront").

To what extent such a situation is peculiar to INC-Cusco compared to the rest of the public sector in Peru is an open question (for health care and education Jumpa et al., 2003, do not acknowledge a similar situation, but rather practices of "double jobs",

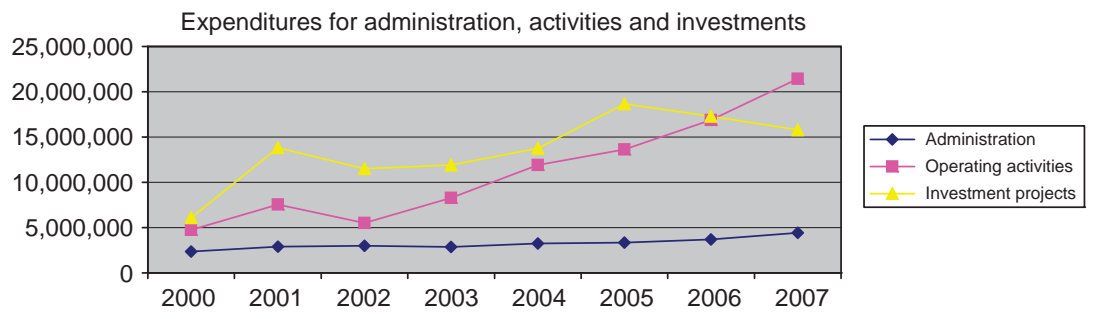

\section{Managing Machu Picchu}

169 
JCHMSD

1,2

170 i.e. doing two jobs at a time). Maybe part of this anomaly is the rich financial situation (and its dynamics in recent years) that allow a significant increase in the number of staff (funding additional jobs, but just in terms of contract positions).

In any case, this seems to put the overall managerial problem in very different terms compared with the rest of the world. While usually the issue is trying to find new forms of development to increase public sector productivity through outsourcing, governance reforms, incentive mechanism and the like, if not privatization initiatives, here the workforce seems to be "manageable" as is rarely the case. Indeed, one could argue, such a situation actually presents risks in terms of the economics of job relations, by negating the economic underpinnings of long-term worker relationships (a la Williamson, 1985).

Looking at the distribution of people in the organizational chart (not including people working on investment projects), interesting elements can be noticed (Table V). Out of the 1,326 people working in administration and operations, about 10 percent (152) work at the top management and central staff, including administration. A very small portion works at the Direction of Cultural promotion (30), while a large number $(1,085)$ work at the Direction of Patrimonio Historico (one can see the effort that the preservation on heritage in the different sites is calling for). Interesting enough, only 186 people work directly at Machu Picchu (where, in addition, other staff from Inrena also work).

\subsection{The financial business model and unforeseen developments}

Following this description, an insight on the business model of INC-Cusco can be pointed out:

- Basically, it is a almost totally self-funded entity, which can use resources from visitors to cover all its expenditures: running costs, labor (though on contract), and investment.

- In terms of internal cross-subsidizing, the most profitable sites (the Inca City of Machu Picchu) are largely funding the entire preservation, restoration, and operation of the region (despite some contributions by the major sites managed by OFEC).

- In terms of dynamics, the impression is that this was to some extent an unforeseen process of development. In particular, the new status after the 2003 reform, the adoption of the new Master Plan in 2005, the establishment of SNIP logic since 2003 and with reference to the various projects of Plan Maestro, all coupled with the increase in the number of visitors - particularly in Machu Picchu: + 74 percent from 2002 - made such a "business model" extremely lucrative for all parties. Even though there are very negative aspects at work, it has been used to a large extend to fund the whole area. No doubt risk remains, as well as externalities that need to be addressed (the visitor pressure criticized by UNESCO, and profits "donated" to private sector rather than used for the sites and archaeological purposes).

\section{Change processes and the master plans}

The issue of planning has become crucial in running the HSM in the last decade. Inclusion in the UNESCO World Heritage list in 1983 required the adoption of management tools and the creation of a management unit in charge of the 


\begin{tabular}{|c|c|c|c|c|c|}
\hline & Permanent & SNP & Recibo & Total & Managing \\
\hline Regional direction, institutional affairs, secretary general, etc. & 5 & 15 & 4 & 24 & \\
\hline Legal affairs, cooperation, and planning & 4 & 16 & 3 & 23 & \\
\hline Staff supervuision, documentation, and acrchives & 11 & 10 & 3 & 24 & \\
\hline Administration & 16 & 50 & 15 & 81 & \\
\hline Total top level & 36 & 91 & 25 & 152 & 171 \\
\hline Direction conservation of immobile heritage & 1 & & & 1 & \\
\hline Museums & 11 & 26 & 45 & 82 & \\
\hline Regional investigations & 8 & 43 & 44 & 95 & \\
\hline Cusco centro historic & 4 & 15 & 0 & 19 & \\
\hline Archeological parks & 7 & 115 & 272 & 394 & \\
\hline Qhapag Nan & 2 & 37 & 41 & 80 & \\
\hline Machu Picchu archeological park & 5 & 147 & 34 & 186 & \\
\hline Sacsayhuaman & 6 & 22 & 57 & 85 & \\
\hline Studies and projects & 5 & 41 & 22 & 68 & \\
\hline Subdirection movable heritage & 3 & 35 & 37 & 75 & \\
\hline Total historical heritage & 52 & 481 & 552 & 1,085 & \\
\hline Production and cultural development & 4 & 8 & & 12 & \\
\hline Culturale events promotion & & 5 & 9 & 14 & \\
\hline INC-UNESCO agreement on living culture & & 1 & & 1 & \\
\hline Activity and research of entodevelopment & & 1 & 2 & 3 & \\
\hline Total cultural promotion & 4 & 15 & 11 & 30 & \\
\hline Total 1 & 92 & 587 & 588 & 1,267 & \\
\hline Subdirection of works & 8 & 3 & 0 & 11 & \\
\hline Others & 23 & 7 & 18 & 48 & \\
\hline Total 2 (Non-including workers on investments projects) & 123 & 597 & 606 & 1,326 & \\
\hline $\begin{array}{l}\text { Workers for investment projects } 2008 \text { for the } \\
\text { sub-direction of works }\end{array}$ & & & & 80 & \\
\hline \multirow[t]{2}{*}{ Workers 2008} & & & & 1,345 & Table V. \\
\hline & & & & 2,751 & Staffing at INC Cusco \\
\hline
\end{tabular}

overall administration of the site. However, in the HSM only sporadic conservation interventions were taken without any logic of coordination, until very recently.

Since 1996 UNESCO has pressured the Peruvian government to adopt adequate management arrangements and comprehensive master planning for the HSM. Therefore in the late 1990s the Peruvian Government and the institutions involved in the management of the HSM gradually started a process of formulation, adoption, and implementation of specific management tools: this marked the beginning of a culture of "managing by plans."

Two Master Plans covering a time range of ten years have been applied so far: one in 1998 (soon abandoned), and one in 2005 (under implementation). The first Master Plan (see box 3 of the appendix ) was required by UNESCO and realized in a top-down fashion by a small team of four external consultants with little involvement of professionals from the local institutions in charge of site management. Indeed, criticisms from the international community (UNESCO and ICOMOS) have been severe on the genericism and lack of operational character of the Plan, also complaining that the strategic planning contents of the document hid implicit strategies and goals (in particular, speculative and political interests concerning the exploitation of tourism flows: e.g., a cableway project to enhance the access to the Sanctuary, regardless of environmental impacts). 
JCHMSD

1,2

172
The second Master Plan (2005) originated from the failure of the previous one, in a context of strong criticism and insistence by UNESCO for the adoption of a new management plan (see box 4 of the appendix). The Plan extensively focuses (one-third of the document) on reviewing the cultural, historical, political, and legislative context of Machu Picchu; the definition of a vision, goals, settings, and strategies are based on this professional understanding. Prior attention is given to the archaeological/ professional dimension; the enhancement of the sacred value of the site, beside the world recognized cultural and natural value; the UNESCO normative framework, beside the national legislation; organizational issues and, particularly, interinstitutional coordination. Minor attention is given to issues concerning tourism exploitation and to the economic value of the site. Interestingly, no attention at all is given to the problem of Aguas Calientes.

In this case the formal planning/goal-setting exercise does not derive from a static, ahistorical, acontextual analysis (the conventional analysis of gaps between an extant situation and a ideal/target situation, in terms of fit between internal resources and external requirements). On the contrary, both the external environment and the Sanctuary itself are presented through a historical and cultural reconstruction of the different logics of action and the different interests and conflicts involved. Hence in this case the Plan seems to be a locus of programming actions and decisions (the last three chapters), but on the base of a deep, prior understanding of the historical, processinformed, contextual meaning, and specificities of a site (the first five chapters).

The 2005 Master Plan can be considered as an operational management tool: despite few inconsistencies, in its detailed tables the hierarchy of objectives, strategies, and specific projects is coupled with timing, allocation of resources, and indication of the funding source at each level (Table VI). Moreover, as we directly observed on site, the Plan Maestro 2005 is a strong reference in the daily practices of administrative, and also professional personnel of HSM (archaeologists, architects, anthropologists). The Plan is widely used as the framework through which they organize their activities, coordinate with other processes, and at the same time make sense of their contributions in a logic of integrated action. Indeed, archaeologists in HSM seem to trust in the Plan Maestro 2005. At all the meetings we had, people were coming with their own copy of the Plan, constantly referring to it: a sort of symbol of "archaeological pride," which was recovering after Fujimori's exploitation of the site.

Although most of the 2005 Plan clearly takes into account concerns by the international community, two elements represent a sort of weakness in the overall picture provided:

- the total lack or reference to the issue of Aguas Calientes: one of the major preoccupations of UNESCO is very rarely referred to, nor is the issue of urban planning addressed adequately. On a crucial issue, the plan is silent; and

- the generous attitude in defining the number of maximum visitors per day, 2,500: a number itself criticized, that can lead up to annual capacity of 912,500 visitors (Instituto Nacional de Cultura (Direccion Regional de Cultura Cusco), Instituto de Recursos Naturale, 2005, p. 96), i.e. a projection bigger than actual figures in recent years. Such a number is more than problematic given the alleged emphasis on the spiritual meaning of the site (it is hard to enjoy the sacred value when you cannot stop more than ten minutes in any one place, in order to keep traffic moving). Put simply, such a mass exploitation seems to be incompatible with high quality and intense enjoyment of the site. 


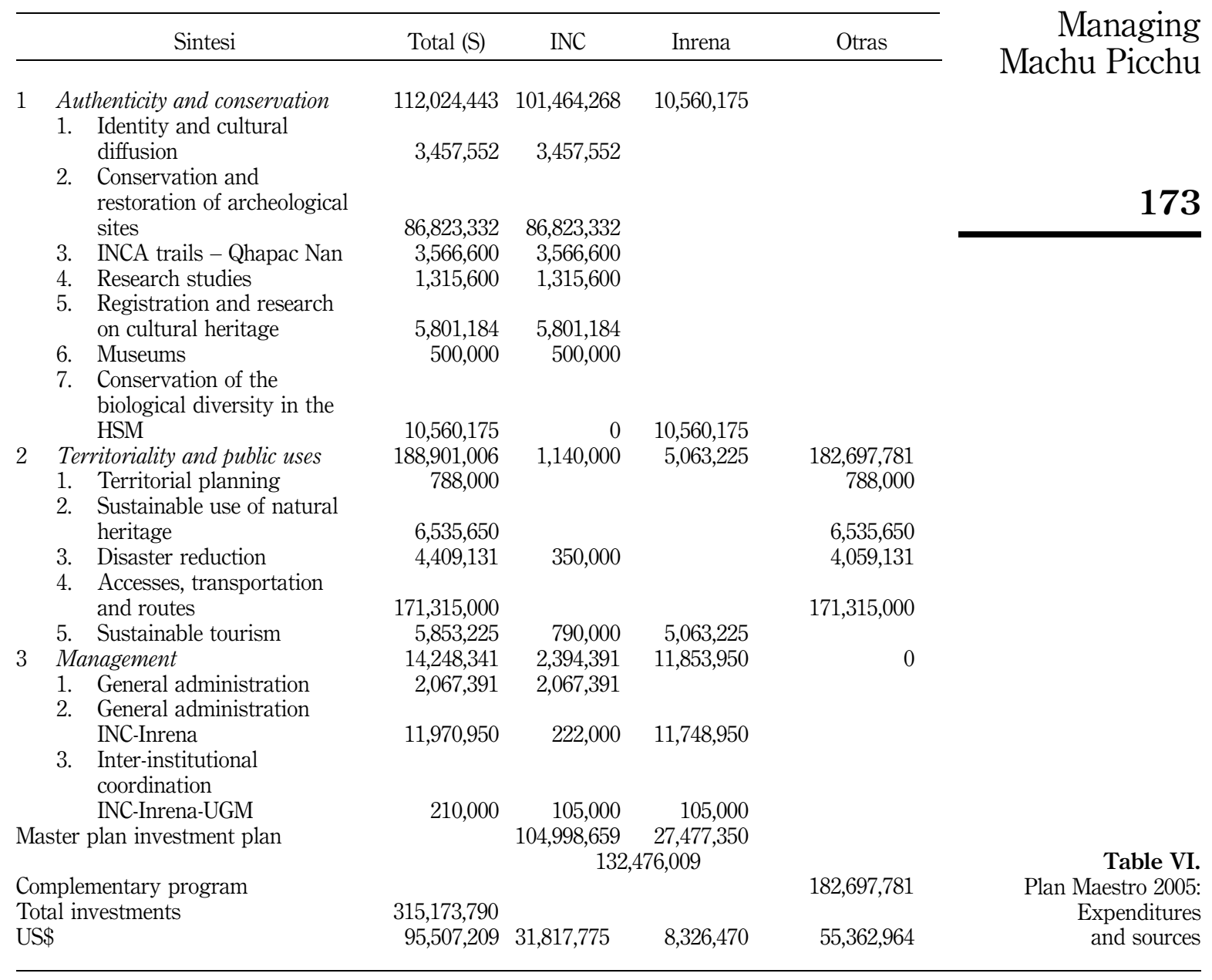

All in all, the role of the Plan seems to have deeply transformed: from the use of the Plan as a ritualistic/political requirement to its use of a managerial instrument, to address attention, set priorities, coordinate flows of actions. Moreover, the importance attributed to Plans has changed (e.g. in the number of people involved in their formulation, in the centrality given to the document, as attested in the interviews).

Searching for major drivers of change, the emergence of master plan practices in Machu Picchu has to be understood in the light of two macro changes in the cultural/ political context:

- the end of an era ruled by corruption, and the beginning of the "modernization" process of the State after the Fujimori period; and

- the influence of the international community administrative culture: the international community (public opinion in general, UNESCO, and World Bank 
JCHMSD

1,2

\section{4}

in particular) also played a central role. Interesting enough, this impact took place at different levels: an overall impact in terms of general policy guidelines (calling for a more curatorial/ecological kind of attitude as a whole), an impact on specific solutions (e.g. fighting the idea of the cableway), and in terms of methodologies that are used and transferred.

UNESCO seems to have played the role of supporting professional views which would have been particularly weak in the absence of such a legitimating role. Most archaeologists we met and talked with were in total agreement with what was asked for/imposed by UNESCO. In a sense, UNESCO itself seems to have acted as giving "voice" to an archaeology value-based view of the whole site. In any case, it acted as support to strengthening the professional view. Moreover, the transference of planning technologies was not a mere standard process: the way in which the plan is structured and its rhetoric (e.g. the lack of a "normal" SWOT analysis in favor of a more substantive analysis of specific issues), can be seen as an original way in which the professional and the managerial dimensions are put in dialogue. It is a pity that in the general debate - in formal documents and the press - the efforts of those fighting "with" international calls for preservation is rarely addressed: finding friends and enemies, acknowledging efforts of the former and responsibilities of the latter is crucial in motivating people and mobilizing actions.

\section{Concluding remarks}

There are just few additional comments that the study of Machu Picchu can address, as general concluding remarks. First, the socially constructed nature of archaeological sites clearly emerges from this narrative. The meanings (De La Torre and MacLean, 2005) - and above all priorities and the ranking between various meanings - largely differ in the two "eras" (Fujimori and post-Fujimori). Or, put in other words, the meanings associated to a site like this cannot be taken for granted, as given. Legitimizing views that are closer - or more compatible - with international values of the profession is a crucial task of international agencies in such a delicate, conflicting process of sense making.

Second, the embeddedness of heritage management in the public sector dynamics clearly appears. It is impossible to talk about the management of Machu Picchu without a huge "introduction," which is indispensable in order to understand the context (structure and changes in the bureaucracy and its internal design, human resource issues, SNIP, and so on). Without such a huge introduction, any comment on data (e.g. people, investments, achievements) would have been not only lacking context, but largely misleading.

Third, rather than simplistic application of management tools to specific fields such as "site management" or "museum management" - what emerges is the inner complexity of any discourse about management in itself. There are not shortcuts to understand the complexity of the management of similar entities, the actual direction, and impact of change processes, merits, and faults of different groups of actors involved. Contextual and processual approaches require a careful use of management studies knowledge. Investigating institutional settings, the underlying business model, and actual managerial practices in planning is crucial for understanding the management of similar entities.

Fourth, the Machu Picchu story gives a central role to the issue of institutional design, as it is often the case (Zan 2006; Lusiani and Zan, 2010). Here a very problematic 
issue concerns the idea itself of governance structure brought in from a management studies background (in a more or less conscious way):

- The underlying concept of "entity," of organizations that are in themselves responsible and self-contained, and thus accountable as such is still alien to most public bureaucracies (not just in developing countries, but in continental bureaucracies as well, as for instance Italy and most of its museums and archaeological sites).

- The underlying assumption that - despite differences in speed and rate - the tendency is a change toward better-defined organizational boundaries of individual operating units (entities) can indeed be questioned, according to our research. Doubt remains whether Machu Picchu, Pompeii, and many other organizations in the cultural heritage sector inside public bodies seem to be willing to move seriously in this direction.

- In any case, understanding the conflictual process of change of partial branches of the public sector - such as museums and sites embedded in broader administrative bodies - is necessary to avoid misunderstandings and costly conflicts. The Unidad de Gestion suggested by UNESCO (and later on by the World Bank) is indeed such a weak institutional solution, compared to what is used elsewhere in similar contexts. For example, in funding the conservation of Quito's historical centre, the Inter-American Development Bank imposed the establishment of a private law public agency with which all transactions and decisions were taken, thus avoiding institutional fragmentation typical of public sector (in Ecuador as elsewhere).

Fifth, Machu Picchu is an extraordinary rich archaeological site, different from most of museums and sites in the world. Interestingly enough, serious problems can be found also in this wealthy situation. There are problems in defining the meanings and concept of the site, e.g. between commercial exploitation and the logic of protection, problems in defining roles and tasks of public and private actors, and problems in finding a possible "third way" between the radicalism of the neoliberal agenda (and the excess of privatization during the 1990s) and the difficulties in making public sector more effective, efficient, and accountable.

Differently from most public sector dynamics, and NPM reforms, here privatization and outsourcing have gone too far, and there is an issue of recovering a (Weberian?) bureaucracy. Ironically, even in such an anomalously rich context, the issue of institutional setting, administrative norms, and above all, the issue of management, become crucial.

\section{Notes}

1. Peru's legislation has always been sensitive to cultural heritage preservation issues (Ley 6439 in 1929); most recent references are the General Law for the Protection of the National Cultural Heritage of 1985 (Ley 24047/1985), and the General Law for Cultural Heritage of 2004 (Ley 28296/2004).

2. Ley no. 27658/2002, Ley Marco de la Modernizacion de la Gestión del Estado.

3. Decreto Supremo no. 017/2003 "Reglamento de organización y funciones del Instituto Nacional de Cultura" in Normas Legales, 2003.
175 
JCHMSD

1,2

176

\section{References}

APEC (2007), "Peru: developments in public sector governance", in Economic Policy Report, available at: www.panamtourperu.com/officialinfo.asp?url = cons (accessed September 30, 2010).

de La Torre, M. and MacLean, M.G.H (2005), Heritage Values in Site Management: Four Case Studies, Getty Publications, Los Angeles.

Giugale, M.M., Fretes-Cibils, V. and Newman, J. (2006), An Opportunity for a Different Peru. Prosperous, Equitable, and Governable, The World Bank, Washington, DC.

ICE (2007), "Perù", Rapporti Paese congiunti Ambasciate/Uffici Ice estero, 2 semestre.

Instituto Nacional de Cultura (Direccion Regional de Cultura Cusco), Instituto de Recursos Naturale (2005), Plan Maestro del Santuario Historico de Machupicchu, Instituto Nacional de Cultura (Direccion Regional de Cultura Cusco), Instituto de Recursos Naturale.

Jumpa, M., Jan, S. and Mills, A. (2003), "Dual practice of public sector health care providers in Peru”, HEFP working paper 06/03, LSHTM.

Lusiani, M. and Zan, L. (2010), "Institutional transformation and managerialism in cultural heritage: heritage Malta”, Museum Management and Curatorship, Vol. 25 No. 2, pp. 147-65.

The World Bank (2002), "Peru: public information notice, World Bank board discusses Peru country assistance strategy", Report No. PIN82, The World Bank.

The World Bank (2006), "Country partnership strategy for the Republic of Peru for the period FY07-FYI1", Report No. 37913-PE, The World Bank.

Williamson, O. (1985), The Economic Institutions of Capitalism, The Free Press, New York, NY. Zan, L. (2006), Managerial Rhetoric and Arts Organizations, Palgrave-Macmillan, Basingstoke.

\section{Further reading}

Karp-Toledo, E. (2008), “The lost treasure of Machu Picchu”, The New York Times, February 23, available at: www.nytimes.com/2008/02/23/opinion/23karp-toledo.html (accessed December 18, 2008).

Leask, A. and Fyall, A. (Eds) (2006), Managing World Heritage Sites, Butterworth-Heinemann, Oxford.

Martorell Carreño, A. (2004), Analisis Critico del Plan Maestro de Machu Picchu. (1998) Propuestas para una Planificación Proactiva en in Bien del Patrimonio Mundial Cultural Y Natural, Icomos, Perú.

National Geographic (2009), "Video: Yale agrees to return Machu Picchu artifacts, Saturday", January 24, available at: http://news.nationalgeographic.com/news/2007/09/070920-incavideo.html (accessed September 18, 2011).

Regalado-Perzua, O. and Arias-Valencia, J. (2006), "Sustainable development in tourism: a proposition for Machu Picchu, Peru”, in Leask, A. and Fyall, A. (Eds), Managing World Heritage Sites, Butterworth-Heinemann, Oxford.

\section{Corresponding author}

Luca Zan can be contacted at: luca.zan@unibo.it

To purchase reprints of this article please e-mail: reprints@emeraldinsight.com Or visit our web site for further details: www.emeraldinsight.com/reprints 
Reproduced with permission of the copyright owner. Further reproduction prohibited without permission. 